Fecha de recepción: diciembre 2017

Fecha de aceptación: marzo 2018

Versión final: julio 2019

\section{Hacer saltar el continuum de la historia. Memoria y representación en imaginarios fotográficos contemporáneos}

Paula Bertúa *

Resumen: El objetivo de este trabajo es indagar, en un corpus de fotografías contemporáneas, la relación entre imágenes y memoria histórica, asumiendo que esta es anacrónica en sí misma y que está atravesada por los efectos del montaje, la reconstrucción y el encadenamiento de tiempos heterogéneos. Sostengo que en la fotografía contemporánea se destaca una línea conceptual que explora el anacronismo, la confrontación entre el pasado y el presente, y que pone en tensión los relatos fundacionales y las narrativas de progreso dominantes en las capitales culturales latinoamericanas entre fines de siglo XIX y principios del XX. A partir del trabajo con fotografías que operan como "imágenes dialécticas", es decir como restos fugaces o relámpagos de legibilidad histórica, las fotografías que analizo condensan indicios del presente y registran restos del pasado, en una propuesta alternativa al memorial, el archivo y la épica, las formas más transitadas en las políticas de la memoria y reconstrucción del recuerdo. Se trata de obras que resitúan sus imágenes en sentidos históricos nuevos, desobedeciendo no solo la cronología sino las causalidades y reconfigurando, de este modo, el sentido histórico establecido. Tomaré como objeto de análisis las obras de: RES, La ruta de Cortés (1999-2000) y NECAH 1879 (1996-2008); Ananké Asseff, "Ananké es necesidad, lo inexorable" (2004-2010); Leonel Luna, Su opulencia es nuestra exclusión, 2001; y Celeste Rojas Mugica, Ejercicios de aridez (obra en proceso).

Palabras clave: fotografía latinoamericana contemporánea - memoria histórica - imagen dialéctica - montaje - discontinuidades.

[Resúmenes en inglés y portugués en la página 183]

${ }^{(*)}$ Doctora en Letras por la Universidad de Buenos Aires, Magister en Historia del Arte Argentino y Latinoamericano por la Universidad Nacional de San Martín y Licenciada en Letras por la Universidad de Buenos Aires. Investigadora del Consejo Nacional de Investigaciones Científicas y Técnicas (CONICET), del Instituto de Literatura Hispanoamericana y del Instituto Interdisciplinario de Estudios de Género (UBA). 
¿A través de qué procedimientos la fotografía puede configurarse como una superficie significante de legibilidad histórica que haga visible aquello que las narrativas tramadas por la historiografía han fijado en relatos hegemónicos? ¿Cómo pueden ciertas imágenes asumir la tarea ética de reabrir el pasado, eludiendo las formas más transitadas en las políticas de reconstrucción del recuerdo y los usos afirmativos de dispositivos visuales de los que son tributarias?¿Cómo dialogan esas imágenes con las tradiciones iconográficas que las fundan y de las cuales a su vez se apartan ostensiblemente? Una línea conceptual de la fotografía argentina contemporánea -volcada a explorar relatos fundacionales del siglo XIX, aquellos que constituyeron el andamiaje simbólico de construcción de la Argentina como Estado- nación- nos ofrece material pertinente para pensar estas cuestiones. En este trabajo propongo analizar algunas obras de res NECAH 1879, (1996-2008), Ananké Asseff (Retazos del paraíso, 2004-2010) y Leonel Luna (La Conquista del Desierto, 2002) que se apropian de imágenes pertenecientes a una tradición visual canónica y las disponen en nuevas constelaciones con sentidos históricos novedosos, desobedeciendo así no solo la cronología sino las causalidades de los hechos históricos allí representados. Se trata de producciones fotográficas que instalan con fuerza la convergencia entre una reflexión sobre la historia y una reflexión sobre la fotografía; sugieren un vínculo entre el pensamiento como memoria y la dimensión técnica del memorizar. Y ponen en juego los problemas de la memoria artificial, la visibilidad de lo que la narrativa histórica habilita recordar, y sus descalces, y las formas que adopta el archivo. Cada una de las obras a examinar demuestra, a su modo, que la fotografía nos acerca y nos aleja simultáneamente de la historia ya que revela la amnesia alojada en el centro del dispositivo, en tanto fotografiar es representar rasgos del mundo que se sustraen del campo perceptivo. Lo que hace, pues, fotografía a la fotografía no es la capacidad de exhibir lo que captura sino su "fuerza de interrupción" (Kracauer, 2008 [1927]).

A la cesura del acontecimiento histórico, a la separación y la discontinuidad a partir de las cuales emerge la historia le corresponde, entonces, una forma de pensamiento y de escritura capaz de contrarrestar el movimiento, una forma fiel a esa interrupción o suspensión (Benjamin, 2008 [1942]). Este dictum es, en principio, aplicable a toda intervención de la técnica fotográfica, en tanto al arrancar una imagen de su contexto se detiene el flujo de los hechos y se interviene en la linealidad de la historia y de la política. Sin embargo, hay prácticas fotográficas -como las que en esta ocasión me interesan-que hacen consciente esa cesura y la exhiben, bajo distintas modalidades, como un procedimiento eficaz para repensar el tiempo, la memoria y la capacidad de los dispositivos visuales para dar cuenta de la complejidad de su construcción. La hipótesis general que guía este desarrollo se afirma en la idea de que las fotografías de res, Luna y Asseff, resultado de un juego con la heterocronía y los tiempos superpuestos, dislocan el orden establecido y trastocan las prácticas de la memoria. Con el uso de operaciones como la elisión, la fragmentación, el reencuadre, la re-fotografía y el montaje, las propuestas de estos fotógrafos irrumpen con nuevas consideraciones sobre el presente, al tiempo que aportan elementos renovados para descifrar el pasado.

El problema de la relación entre la duración y el recuerdo está inscripto en el propio artefacto técnico, ya que el acto fotográfico produce un intervalo, un desfasaje que, siguiendo a Henri Bergson, podemos llamar "memoria”. El vínculo entre dispositivo fotográfico y 
pensamiento es explicado por el filósofo en términos de una analogía técnica que ilustra el funcionamiento de la memoria y de la máquina fotográfica (Bergson, 2006 [1896]). Esa memoria es la duración en un sentido amplio, consiste en hacer fluir el tiempo por fuera de la imagen ya que es en la espera que el tiempo puede refugiarse mientras se desvanece la imagen y donde surge el durar diferenciado y el devenir de los instantes. La dimensión temporal que la fotografía instaura no solo vuelve hacia el pasado, sino que apunta hacia adelante, a un movimiento de expectación y es en esa apertura hacia el futuro que la fotografía "piensa" (Lissovsky, 2003). Lo que cabe a la espera, en la ética del instante de la fotografía, es resguardar el futuro y, en el interior de éste, la temporalidad del acontecimiento y de la diferencia.

A partir de estas consideraciones me interesa llevar la atención hacia las obras consignadas en tanto se trata de propuestas visuales que reactualizan el problema de la relación entre arte y política, pronunciándose sobre la Historia y asimismo sobre las posibilidades de la imagen técnica para configurar narrativas acordes con una experiencia de la temporalidad atravesada por la crisis de la representación. Por un lado, esto implica pensar la construcción del sentido histórico desde cuestionamientos a la historiografía progresiva y desde lógicas no hegemónicas en la conceptualización del tiempo. En este sentido, las fotografías en las que me voy a detener interpelan el tiempo para transformarlo y ponerlo en relación con otros estratos de la historia; plantean una relación entre tiempos caracterizada por la discontinuidad, que vuelve a esa fractura el lugar de una cita y un encuentro entre las generaciones (Agamben, 2011). Y hacen emerger lo intempestivo, una temporalidad que interrumpe la supuesta continuidad del devenir histórico e introduce lo nuevo. Encuentro en los aportes de Reinhart Koselleck nociones fundamentales para pensar las imágenes fotográficas con las que trabajaré, como intentos deliberados de construir temporalidades alternativas a la Historia. Los conceptos de "espacio de experiencia", un pasado acumulado que contiene estratificaciones a ser descubiertas, y de "horizonte de expectativa", el futuropresente, la espera como espacio de agenciamiento, resultan productivos para indagar en la significación ética y política de los acontecimientos de la historia (Koselleck, 1993 y 2001). Analizar los sentidos históricos en el arte -y en este caso particular en la fotografía- implica distinguir entre los acontecimientos y la narración de los mismos; conjugar memoria y olvido, imágenes e ideología, sincronía y diacronía, historia y representación. Por otro lado, en cuanto a las relaciones entre historia y memoria ${ }^{1}$, resultan sustanciales las reflexiones teóricas de Maurice Halbwachs sobre la memoria colectiva como una instancia selectiva, política e ideológica en tanto cada individuo y comunidad seleccionan los recuerdos que conservan de acuerdo con las relaciones de poder dominantes en determinado espacio y lugar (2004a [1925] y 2004b [1950]). Halbwachs advierte asimismo que no es fácil definir cuándo un recuerdo colectivo ha salido de la conciencia común, pero es suficiente que se conserve en alguna parte del imaginario social para que pueda ser descubierto una vez más. En relación con la memoria en el campo de las representaciones artísticas, las propuestas fotográficas que me interesa examinar ponen en cuestión lo que subyace latente en el imaginario y en el lenguaje para indagar los modos de representar eso que se torna esquivo por su impacto disruptivo sobre el cuerpo social, sus espacios, narrativas e instituciones. 


\section{Contrapuntos y alternancias: otros modos de tramar la historia ${ }^{2}$}

En una entrevista que Ignacio Bisbal realiza a res, ante la pregunta por la forma de documentar sus trabajos y la naturaleza del proceso que se extiende desde la concepción a la realización, el fotógrafo ofrece una respuesta que funciona como una suerte de declaración de principios sobre su modo de operar con las imágenes:

La fotografía me interesa por su peculiar relación con el tiempo, que veo muy próxima a mi procedimiento de trabajo más frecuente: evocar un hecho del pasado para que active el presente, para que actúe y nos interpele. A propósito, algunos de los pasajes de las Tesis sobre la filosofía de la historia de Benjamin, ¿no serán el resultado de décadas de práctica fotográfica? (res, 2018 julio, s/n)

La reflexión de res resulta elocuente como cita y línea de entrada a su obra. Como es sabido, la relación entre memoria y fotografía ha sido extensamente estudiada desde el análisis histórico y cultural, en tanto la fotografía es un procedimiento, un lugar de inscripción y el archivo de un pasado. Sin embargo, Walter Benjamin matizó esta concepción proveniente del historicismo, al reconocer en la memoria técnica de la fotografía antes que la conservación idéntica de lo que ha sido, una instancia de interrupción, "(...) una fractura originaria de todo pasado que pueda llegar a inscribirse como imagen" (Collingwood-Selby, 2009, p. 174). Asimismo, el dispositivo fotográfico favorece, a partir del corte espacial y temporal que se ejecuta en cada disparo del obturador, un pensamiento de lo discontinuo, un "(...) tiempo de la singularidad donde cada toma produce un agujero, un tiempo del propio latido temporal, una memoria sutil” (Dubois, 2008 [1990], p. 152).

Esta matriz del intervalo, en sus múltiples significaciones, resulta central para pensar la obra de res desde sus series tempranas hasta los trabajos contemporáneos que consisten en acciones cuyo registro en fotografía y video, parte o momento fundamental y constitutivo de la propuesta, es compartido en distintas plataformas virtuales ${ }^{3}$. En principio y de forma general porque, por sus propiedades técnicas y de funcionamiento, la fotografía instaura un tiempo basado en la distancia fundante entre un real que ya no está presente y una imagen que todavía no llegó; su dominio temporal es, pues, el del intervalo. Pero además porque res apela a esa interfaz de significados y afectos habilitada por el dispositivo técnico como un instrumento potente de des-territorialización para examinar las prácticas intervalares de la diferencia, las dislocaciones de las genealogías y las fracturas en la construcción de la memoria. Como afirma Diego Tatián, el trabajo de res con la fotografía adopta la forma de una "arqueología política" (2018, s/n). Una tarea paciente cuyo propósito es desmontar procesos inscriptos en una temporalidad expandida a lo largo de varios siglos de historia del subcontinente, signados por la conquista y la colonización, el exterminio y la transculturación.

Para elaborar el ensayo fotográfico NECAH 1879 (1996-2008), res recorrió el mismo itinerario que el fotógrafo Antonio Pozzo a finales del siglo XIX, cuando este acompañó a las tropas comandadas por Roca, documentando en imágenes la etapa final de la llamada "La campaña al desierto" ". Las fotografías de Pozzo, que a su regreso editó en un álbum de alrededor de cincuenta piezas titulado Expedición al Río Negro, muestran los batallones de 
Roca, los indios doblegados, los extensos territorios que habitaban y sus fortines. La serie NECAH 1879 se compone de varias zonas ${ }^{5}$. En primer lugar, hay una imagen central, dividida en dos, de un fusil Remington en corte vertical, parte indispensable de "la santísima trinidad" junto con el telégrafo y el ferrocarril, al decir de David Viñas, que se refería con ese símil a las coordenadas del ideologema "orden y progreso" en nombre del cual se legitimó el genocidio indígena (1982, p. 17). En segundo lugar, encontramos una serie de dípticos con las reproducciones de las fotografías de Pozzo en blanco y negro y las tomas en color de res sobre los mismos territorios. Las fotografías de res se detienen en los vestigios de aquella empresa de exterminio, como el cementerio de Choele - Choel emplazado en el terreno donde se había asentado la tienda de campaña de Roca y los Jefes de la Primera División Expedicionaria; o la Plaza Alsina en el partido de Puán, al sur de la provincia de Buenos Aires, que ostenta un monumento alusivo al líder que inició la campaña de extensión de la frontera hacia el sur, allí donde en 1879 Pozzo había retratado a los Coraceros. Por último, una tercera zona del ensayo comprende una serie de fotografías en blanco y negro, tomadas desde enfoques distintos a los de Pozzo. Cada una de ellas exhibe en primer plano una letra y en conjunto construyen la frase atribuida al cacique Calfucurá convertida en consigna de resistencia y lucha frente al blanco: "No entregar Carhué al huinca" (Imagen 1). “¿Cómo materializar la emoción que produce una letra agitada en el viento?” se pregunta el artista, asumiendo el desafío de pensar al lente "no como límite, sino como vínculo" con una memoria que pulsa en el presente (res, 2018, 19 de septiembre).

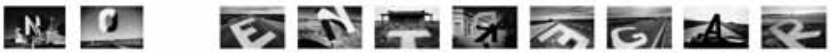

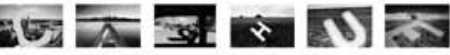

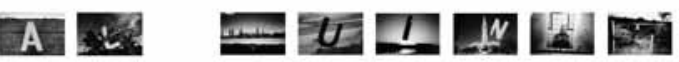

Imagen 1. Res, No Entregar Carhué Al Huinca, 1996 (políptico)

Respecto de la obra de res, la crítica Valeria González ha afirmado que en ella predomina una "lógica del palimpsesto". En tanto la superposición de capas y estratos de imágenes inscriptas sobre una misma superficie, gracias a largos tiempos de exposición, generan apariciones fantasmagóricas y construyen formas especiales de memoria social "viva" donde se van acumulando voces, autores y épocas (González, 2006, pp. 184 y 185). También agrega que a partir de 1996, si bien res siguió apelando a esa matriz compositiva en la construcción de imágenes, comienza a explorar formas novedosas de relación entre la fotografía y el tiempo (op. cit., p.186). En efecto, en sus trabajos de largo aliento el fotógrafo acuña una poética que juega con el contraste, la diferencia y el anacronismo entre imágenes distanciadas entre sí por lapsos temporales variables que van de un instante a toda la vida, o a grandes tramos de la historia. 
En NECAH 1879 el contrapunto temporal entre imágenes es explícito: a las fotografías de época de Pozzo se le oponen sus dobles contemporáneas tomadas en los mismos escenarios. La mayoría de esas transposiciones y montajes temporales corroboran, no sin abatimiento, el triunfo de "la civilización sobre la barbarie", por ejemplo las fotografías que muestran un colector de energía solar en el lugar que estaba emplazado un fortín o un entramado urbano donde antes se encontraba el Cerro de la Caballada (Imágenes 2 y 3). Sin embargo, otras piezas responden a la demanda de lo que la historia está condenada a olvidar y rinden justicia a los vencidos, otorgando visibilidad a los sin nombre, a los pueblos condenados a desaparecer, como el retrato grupal de los descendientes del cacique indígena Linares (Imagen 4). En este sentido, puede aventurarse que la apuesta estéticopolítica de res pone en discusión un orden social naturalizado, a través de lo que Jacques Rancière denomina la "partición de lo sensible": ese espacio del logos en que se define la subjetividad de los que no tienen parte, voz o representación. Esta forma de actuación del arte propone una manera de reflexionar sobre la dimensión de lo político como momento de quiebre que posibilita la reasignación de lugares y la reconfiguración de nuevas visibilidades de discursos, identidades y subjetividades (1996).
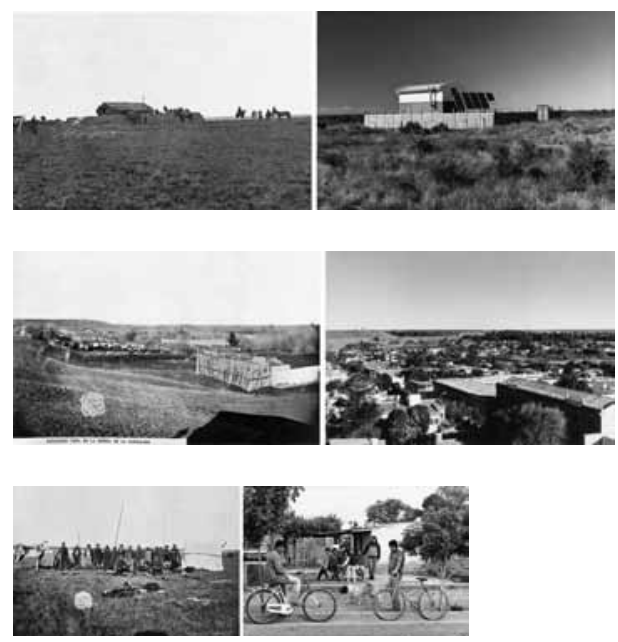

\author{
Imagen 2 (arriba). \\ Antonio Pozzo. Fortín \\ próximo a Puán, 1879 / \\ res. Colector de energía \\ solar próximo a Puán, \\ 1996 (díptico). Imagen 3 \\ (centro). Antonio Pozzo. \\ Cerro de la Caballada, \\ 1879/ res. Cerro de la \\ Caballada, 1996 (díptico). \\ Imagen 4 (abajo). \\ Antonio Pozzo. El \\ cacique Linares y su gente, \\ Choele-Choel, 1879/ res. \\ Descendientes del cacique \\ Linares, Choele-Choel, \\ 1996 (díptico)
}

Hay una fotografía que, en cierto sentido, clausura NECAH 1879: es la que res tomó el 24 de julio de 2008 durante la lectura de la sentencia de Luciano Benjamín Menéndez y otros represores implicados en el asesinato y la desaparición de personas durante la última dictadura militar en la Argentina ${ }^{6}$. Como se conoce, el fallo fue el primero en el que la justicia nacional le impuso a un jefe del ejército sentenciado por delitos de lesa humanidad 
cumplir su condena en una cárcel común. Esta fotografía se instala en el debate acerca de las políticas de la memoria sobre el pasado reciente y su representación. Imbricada en el cruce entre estética y política, memoria y trauma, duelo y justicia, la fotografía de res se ve atravesada por interrogantes que acucian a las producciones culturales sobre la memoria en la posdictadura: ¿cuál es el estatus del dispositivo artístico en el reclamo de una ética de las imágenes?; ¡cuáles sus posibilidades y sus alcances? La fotografía de Menéndez, por su carga de denuncia, se puede filiar con el activismo y por visibilizar ese "instante de verdad" en que la historia hace justicia responde con contundencia a la demanda ética planteada al arte que trabaja con la memoria: la exigencia de una imagen justa. El gesto de res de incluir esa fotografía extemporánea en el conjunto de la conquista del desierto es elocuente: con el juicio a Menéndez la historia viene a condenar-de modo simbólico, desplazado y anacrónico- a Roca como autor material de un genocidio que prefigura -por su magnitud, crudeza e impunidad- la violencia de Estado desplegada durante la última dictadura militar.

\section{El trabajo del sueño: rememoración, montaje, inversión}

El mundo visual que evoca la obra de Ananké Asseff está hecho de escenas y suspensiones, imágenes robadas al sueño y restos de imaginería de la industria audiovisual, espacios vivenciales anclados en contextos precisos. Los desplazamientos entre el yo, la naturaleza y lo social que sus fotografías, videos e instalaciones dan a ver traman una narrativa donde la violencia y la amenaza sobre los cuerpos es cifra de los miedos más atávicos.

Retazos del paraíso es una serie de autorretratos, elaborada entre 2004 y 2010, en paralelo a otros de sus proyectos fotográficos, y que tuvo como origen la experiencia de la crisis del 2001. Según Asseff, la situación de vulnerabilidad que planteaba ese escenario convulsionado por los cambios políticos y sociales del momento la llevó a buscar refugio en espacios más intuitivos, relacionados con la belleza y la protección, lugares que, en su obra, sin embargo, lejos de simbolizar locus amoenus, ponen en tensión un adentro y un afuera, sensaciones de encierro y libertad, seguridad y amenaza. Retazos del paraíso es simultánea y en cierto sentido la contraparte, una versión en negativo del reconocido trabajo Crímenes banales (2005-2007), una serie que retrata a gente común portando armas de fuego en la intimidad de sus hogares. Y que puso en escena la inseguridad ciudadana, fomentada por los medios de comunicación, como moneda corriente de la vida en comunidad en la contemporaneidad. En ambas series, la fotógrafa trabaja volviendo compleja la relación entre espacios interiores y exteriores. Los dos ámbitos pueden convertirse, a su modo, en amenazantes: los primeros por sembrar en aquello que es familiar indicios de lo siniestro; los segundos por sugerir lo sublime.

Retazos del paraíso enfrenta al espectador con diversos escenarios naturales, espacios abismales y misteriosos, rincones de la naturaleza que, por su inmensidad, evocan lo sublime. En esas imágenes -conjunción de paisaje y autorretrato- se distingue la figura de Asseff que los transita, ocupa o habita momentáneamente mientras dura la toma. Escondidas, sumergidas, de espaldas a la lente, siluetas y sombras parecen querer sustraerse a un paisaje que anuncia lo irrepresentable. Recordemos que lo sublime, categoría ampliamente 
examinada por una tradición que recoge los nombres de Longino, Burke o Kant, afecta al sujeto a través de lo sensorial y, en una segunda instancia, poniendo en funcionamiento su razón. El arte, que opera en ese pródigo intersticio entre la estética y la ética, tiene la potencialidad de representar las imágenes que no se pueden tolerar, los espacios abismales, la muerte y el miedo, a través de la codificación simbólica, metafórica o metonímica, logrando que podamos experimentar un goce estético ante lo bello de lo terrible (Fajardo, 2012, p. 180).

En la propuesta de Asseff hay algo que descoloca o que en cierto sentido frustra las expectativas de un encuentro con aquello que por su carga disruptiva amenaza el núcleo de la representación. En virtud de un contrapunto entre lo que ella declara sobre su obra -“(...) la amenaza está solapada en la belleza. Lo tenebroso convive con lo sublime” (Asseff, 2012, p. 139)- y lo que muestra, las imágenes de la serie operan en los marcos de una estetización del paisaje y de la figura que aparece en él. Este gesto que atenúa la carga inquietante que esos espacios presuntamente inconmensurables podrían insinuar -se trata de lo novedoso sin peligro- produce un devenir hacia lo que podríamos llamar un sublime irónico. Es decir, se roza con ligereza lo insondable y se juega con el contraste entre lo declarado y lo plasmado visualmente, en términos que pueden entenderse como una provocación al espectador, al que ella llama "interactor" por el tipo de actuación que demanda en la recepción". Otras zonas de esa serie, como el video interactivo "Contemplación II", tensan la relación entre la belleza del paisaje y la amenaza de la mirada, invirtiendo los términos entre sujeto y objeto, aquel que mira y el que es mirado se vuelven intercambiables. En una primera fase, una mujer contempla de espaldas a la cámara un lago en un bosque que se extiende ante sus ojos. Si el espectador mantiene una distancia prudente, la escena se sostiene, pero si se acerca, un sensor se activa y la mujer gira su rostro hacia él, quebrando con esa contemplación extasiada del escenario natural. Si nos aproximamos más a la escena, descubrimos que el personaje femenino es la propia Ananké.

Igualmente iconoclastas son sus referencias, mediadas por la imagen técnica, a obras reconocidas de la historia visual de Occidente, aunque ella asuma no trabajar con citas de

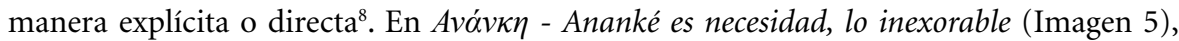
componente de la secuencia Retazos del paraíso, la artista parte de una imagen que se le presentó en sueños:

Ananké, una fotografía en la que voy cabalgando con ropa ligera llevando a un hombre que me toma de atrás. No se ve la cara del hombre, sólo sus piernas y sus brazos rodeándome en ese galope brioso y en el medio de un campo abierto y ondulado. Lo soñé exactamente así, me desperté, lo escribí todo y me volví a dormir. Luego tuve que producirla (Asseff, 2011, 12 de noviembre, s/n; el énfasis es mío).

La escena expresa una necesidad contenida in nuce en el nombre ' $A v \alpha ́ v \kappa \eta$ en griego, que significa inevitabilidad, compulsión, lo ineludible. Asseff genera una representación fotográfica alternativa de la cautiva, una de las figuras fundacionales de la cultura argentina y un motivo privilegiado de la literatura y la pintura del siglo XIX. En efecto, el arte no ha dejado de recrear el argumento de esta historia cuyo origen se remonta a los relatos de la 


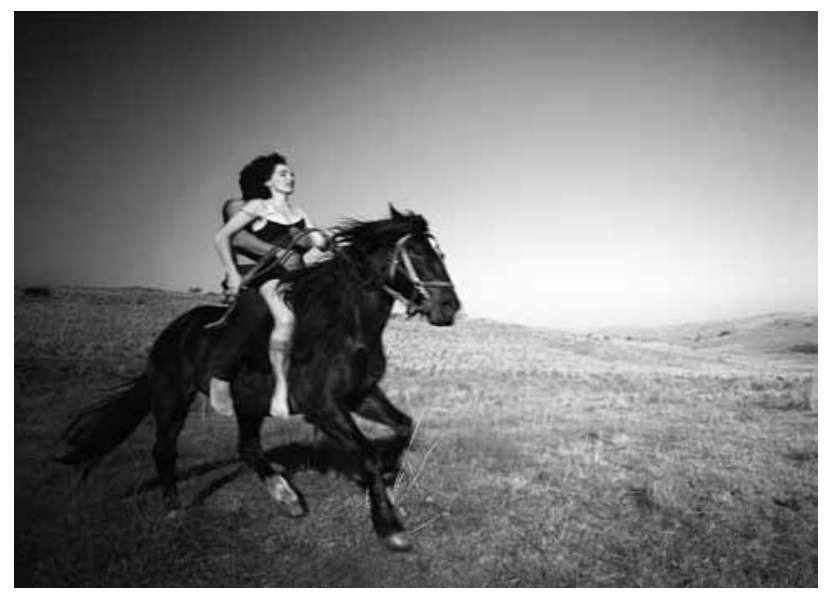

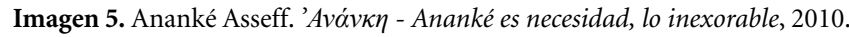

Conquista y a la mítica figura de Lucía Miranda, la española cautiva por los indígenas. La iconografía de esa mujer que se interna en la tierra de los indios para rescatar a su esposo capturado por un malón constituyó, como se sabe, un vehículo ejemplar en la transmisión de idearios y valores de las élites dirigentes que, inspiradas en la ilustración francesa, veían en la "civilización" y el "progreso" un estado ideal, universal hacia el cual la humanidad se inclinaría naturalmente en su evolución. El sentimiento de lo sublime también puede expresarse en la historia realizada como fenomenología de un poder racional económicopolítico que, al tiempo que funda utopías de emancipación e igualdad, impone regímenes de terror y dictaduras basadas en principios como: horror y razón, monstruosidad y belleza (Fajardo, op. cit., p. 185). La obra de Asseff establece guiños reconocibles, tanto literarios como visuales, con el relato de Esteban Echeverría y en especial con La vuelta del malón, el famoso cuadro de Della Valle que fue enviado a la Feria de Chicago en conmemoración del IV centenario del descubrimiento de América, como parte de un programa que, en nombre de la razón y de su universalismo, aniquiló civilizaciones indígenas (Imagen 6). En principio porque, por sus grandes dimensiones ( $1,77 \mathrm{~m} . \times 1,27 \mathrm{~m}$.), la fotografía juega con la jerarquía de los cuadros del género histórico. Y también porque la imagen que produce altera el sentido de la mirada: desde una perspectiva de género, subvierte los signos en la representación de la mujer (la cautiva) y la figura masculina (el indio) que la acompaña, despojando a la representación de sus conocidas connotaciones políticas, e invirtiendo las relaciones de dominio de esa iconografía largamente frecuentada. La fotografía, con el uso que de ella hace Asseff, se constituye así en un dispositivo poderoso para habilitar una nueva lectura, una lectura a contrapelo de la historia; la protagonista de la escena no parece pasiva o indefensa, ni estar prisionera o sometida a los designios del varón, sino que conduce al galope internándose en el campo abierto, asumiendo aquello que es inexorable: su deseo. 


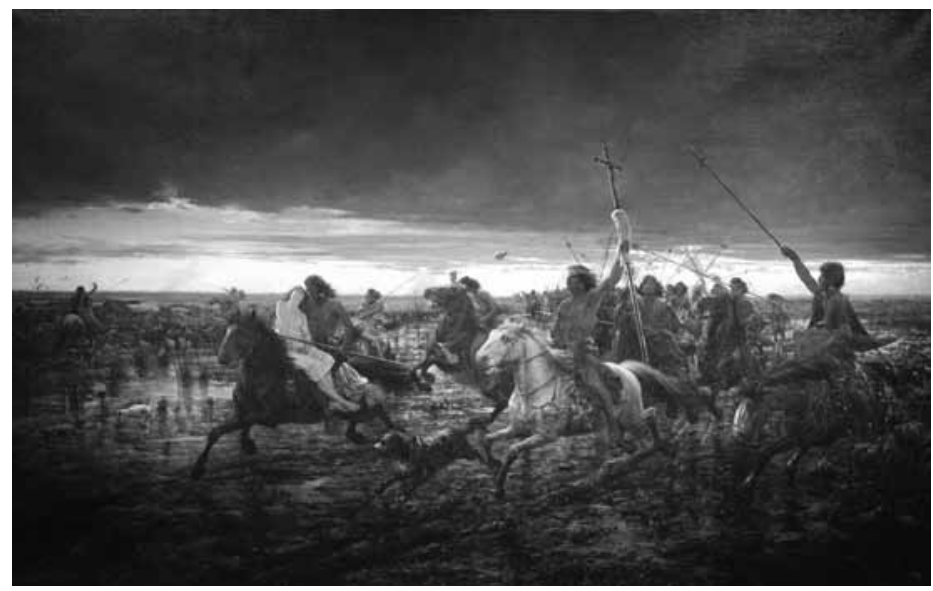

Imagen 6. Ángel Della Valle. La vuelta del malón, 1892.

\section{Citas, mediaciones y dispositivos para una historia no progresiva}

En un tiempo donde las imágenes han perdido su aura, recobrar su misterio pareciera anacrónico y a la vez necesario. Existen obras que contribuyeron a conformar nuestro imaginario histórico e identitario, obras que aún hoy mantienen su perturbadora belleza más allá del registro o de la crónica ¿Por qué no podemos hoy ser cronistas y poetas y construir nuestra propia epopeya cotidiana? (Luna, 2004) ${ }^{9}$

Estas palabras del artista visual Leonel Luna resumen con justeza la inquietud que anima el extenso cuerpo de su obra, donde la cita directa y la reapropiación de obras emblemáticas de la tradición artística fundan operaciones complementarias e indispensables para reabrir los relatos cristalizados por la historiografía. Resultado de un estudio meticuloso de fuentes visuales, históricas y literarias, Luna se aboca a versionar, con medios fotográficos, escenas de la pintura histórica, para leerlas a la luz de la historia del presente. Sugerente operación que conjuga dispositivos dotados de una historicidad propia, así como de formas específicas de representar y construir memoria. Porque si la pintura sigue los lineamientos heredados del aparato perspectivo renacentista en su recorte del instante y en la jerarquización del espacio figurado, la fotografía, en cambio, instala una temporalidad doble que registra desde un presente la desaparición de lo sensible, motivo por el cual deviene un modelo privilegiado para la reescritura de la historia (Déotte, 2013, p. 276 y ss). 

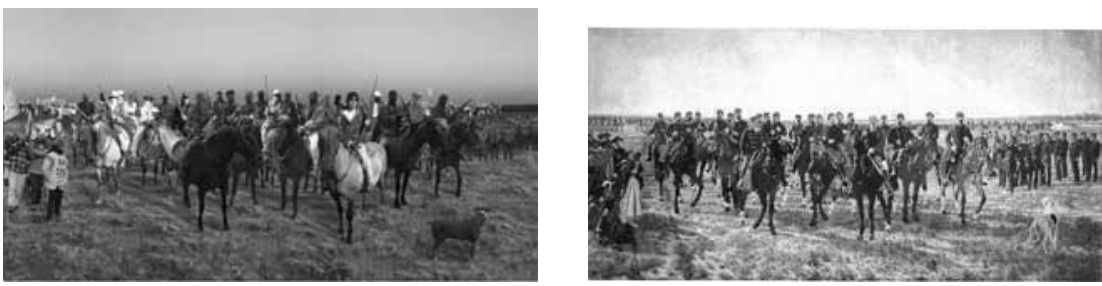

Imagen 7 (izq.). Leonel Luna. La Conquista del Desierto, 2002. Imagen 8 (der.). Juan Manuel Blanes. La ocupación militar del Río Negro, 1896

$\mathrm{Al}$ momento de elegir una imagen que nos acerque a su trabajo, Leonel Luna se inclina por una fotografía que considera emblemática: La Conquista del Desierto (impresión sobre vinilo, 1,80 m. x 3,60 m., 2002). En un ejercicio autodescriptivo de su obra, explicita las fuentes y la técnica que utilizó, así como también esclarece datos sobre el contexto de producción ${ }^{10}$. Se trata de un collage fotográfico de grandes dimensiones, compuesto por más de treinta y cinco tomas realizadas con una cámara digital de 1 megapíxel de uso ordinario, que le llevó varios meses de producción y posproducción (Imagen 7). La pieza de Luna se basa en la célebre obra de Juan Manuel Blanes La ocupación militar del Río Negro por la expedición al mando del Gral. Julio A. Roca, encargada en 1889 por el Ministerio de Guerra y Marina, con motivo del décimo aniversario de la Expedición al Desierto de 1879 y con destino a ser alojada en el Museo Histórico Nacional (Imagen 8$)^{11}$. Ese óleo de grandes dimensiones ( $3.35 \mathrm{~m}$. x $7.10 \mathrm{~m}$.) es una representación figurativa en formato horizontal que posiciona al Gral. Julio A. Roca dominando el centro de la composición, en la celebración del día de la Independencia a orillas del Río Negro el 25 de Mayo de 1879. Es una escena de carácter épico, monumental y ornamental. Para ejecutar su interpretación de ese cuadro, Luna versionó a cada uno de los jinetes como civiles en armas, en pose frontal, con pañuelos en el rostro para proteger su identidad. Estos personajes se encuentran rodeados por manifestantes y, en una instancia más alejada, aparece un grupo de policías; son todas imágenes que el fotógrafo tomó durante las manifestaciones del 2001.

Me interesan las recursividades entre períodos y dispositivos técnicos involucrados en la obra de Luna porque permiten visibilizar varias cuestiones que su obra pone en juego respecto de las funciones y valores atribuidos a la fotografía, su relación con la historia, y los poderes que determinadas representaciones tienen al ser activadas en coyunturas específicas. En principio, el óleo de Blanes -epítome de la pintura de género histórico, parte del aparato simbólico del proceso de formación del Estado-nación-incorpora como referentes en la composición fotografías. En cuanto al motivo, se trata, hemos de recordar, la revista militar del 25 de mayo de 1879 a orillas del Río Negro. El lienzo monumental exhibe a un grupo central de personajes conformado por veintidós retratos ecuestres, con el General Roca en el centro, cercanos a él los funcionarios de su Estado Mayor y más 
alejadas otras figuras secundarias ${ }^{12}$. En el proceso previo a la ejecución, Blanes se documentó extensamente, entrevistando a historiadores y protagonistas para informarse sobre las particularidades de ese suceso histórico. Como afirma Roberto Amigo Cerisola, "El cuadro es el resultado de una compleja sistematización de recursos pictóricos heredados para construir la ilusión de verdad que le permita al espectador, conocedor del período, percibir inmediatamente el asunto" (1994, p. 327). Esa construcción imaginaria, agrega Amigo, asienta su verosimilitud en determinados elementos de ese pasado -grabados, uniformes, sabes, medallas- dentro de los cuales, remarco, la fotografía, ocupa un lugar central, privilegiado. Blanes hace comparecer en la misma escena a un conjunto de personajes del espectro militar y político a partir de una transposición de sus fotografías (práctica habitual en la pintura del siglo XIX) es decir, imágenes ya connotadas por el realismo indiciario del que eran portadoras. Así, la fotografía viene a atestiguar el esto ha sido de una imagen tan fraguada cuanto eficaz en su función ideológica: transmitir un mensaje moral y fortalecer el sentimiento de pertenencia dado por ese hito que significaba la avanzada de la civilización sobre el desierto.

Luna, como he adelantado, se basa en la obra de Blanes, cuyo emplazamiento monumental en el Museo Histórico sellaba una instancia decisiva de legitimación del relato nacional, al tiempo que reafirmaba el ingreso de la Argentina en el proceso de la civilización. Un gesto elocuente de la tradición conservadora que adopta “(...) esa 'Conquista' como mito de origen de la Argentina moderna” (Masotta, 2006, p. 227) ${ }^{13}$. La apropiación de Luna actualiza los sentidos de la escena en relación con sucesos de la historia argentina reciente, lo que se traduce, ineludiblemente, en desplazamientos en los términos de la representación: aquellos personajes que aparecían en posición subalterna en el cuadro original -correlato de una subordinación en el marco del orden social del s. XIX- asumen protagonismo como nuevos actores de la historia y sujetos políticos. De este modo, los representantes de las movilizaciones populares -manifestantes, civiles, piqueteros- ocupan el centro de la composición, en tanto que los policías aparecen en una posición secundaria. No resulta aventurado observar en el intercambio establecido entre el fotógrafo y los fotografiados la mediación de un contrato singular que se actualiza en momentos de crisis políticas y sociales, tal como lo concibe Ariella Azoulay, es decir como un pacto tácito que puede funcionar como refugio cívico que otorga imagen a sujetos habitualmente subrepresentados (Azoulay, 2008).

Los reenvíos entre medios y acontecimientos de la historia, dados por los diversos modos de apropiación de imágenes precedentes y estrategias de construcción de nuevas configuraciones, se relacionan con las apreciaciones de Viviana Usubiaga sobre ciertas prácticas apropiacionistas en el arte contemporáneo: las obras que recurren a imágenes de la historia del arte a través de la pintura, la fotografía o un cruce de ambas “(...) redefinen las concepciones sobre el propio arte y el rol de las prácticas artísticas en la sociedad contemporánea” (2012, p. 414), al tiempo que habilitan “(...) pensar y reescribir la historia del arte y de la cultura local en una temporalidad compleja” (ibid.). Al igual que la obra de Asseff que se analizó en el apartado anterior, la pieza de Luna tiene como origen pero además en su caso convierte en motivo escenas de la crisis del 2001, una coyuntura que, como se sabe, desbordó el campo económico para alcanzar la dimensión de un proceso social generador de nuevos protagonismos, de formas inusitadas de acción política y de estra- 
tegias simbólicas y materiales reivindicativas y de supervivencia. De este modo, podemos afirmar que la propuesta de Luna se inscribe en la línea conceptual que Laura Malosetti identifica en una tendencia del arte contemporáneo que retoma pinturas del pasado, “(...) no para parodiarlas ni para legitimarse a sí mismas sino para reinventar la tradición en función de los desafíos actuales" (2006, p. 5). Es decir, esos usos y reapropiaciones de obras canónicas se orientarían a la construcción de pautas identitarias de resistencia, inscriptas en planteos que resignifican los sentidos originales de esas piezas en contextos históricosociales específicos, donde los poderes de las representaciones se activan, de muy diversos modos, en diálogo con el presente.

\section{Palabras finales}

En un ensayo sobre la política de las imágenes, a propósito de la obra del chileno Alfredo Jaar, Georges Didi-Huberman perfila la encrucijada que signa la economía actual de imágenes de violencia o barbarie, que se dirime entre los polos de la censura y la demasía. Es decir, desde los medios, estamos permanentemente expuestos a no ver nada o a ver solo clichés. Esta suerte de diagnóstico de los modos y objetos de visibilidad en la cultura informacional contemporánea es apenas un preámbulo para entrar en el problema que a Didi-Huberman le interesa tratar: ¿de qué formas puede el arte dislocar la mirada, implicándola en aquello que nos concierne? (2008, pp. 39-44). Considero que esta preocupación es pertinente para pensar cómo las obras de res, Ananké Asseff y Leonel Luna que he analizado logran una comprensión implicativa de la historia. Mediante el trabajo de crítica y desglose al que someten a imágenes e imaginarios largamente consolidados en la memoria social, sus proyectos fotográficos producen un conocimiento que funde sujeto $\mathrm{y}$ objeto, $\mathrm{y}$ en el que las elecciones formales no pueden desprenderse del acontecimiento afectivo ni de la historia. No es casual que los tres artistas aparezcan en algún lugar de las escenas figuradas, inscriptos o, mejor, fundidos en la representación-Asseff como cautiva; Luna en el lugar de Roca; res en un autorretrato que refleja su rostro en un espejo-. Porque atreverse a abrir los documentos y hacer saltar el continuum de la historia requiere de un cuerpo a cuerpo con las imágenes, con los sentidos depositados en ellas, con sus usos, proliferaciones o negaciones. En un momento en que se debate acerca de la crisis de los usos de la fotografía respecto de la cuestión ética de la relación entre lo representado y sus formas, propuestas como las examinadas -que penetran en las entrañas de los dispositivos visuales, como pregonaba Flusser- nos instan a reflexionar sobre la incertidumbre de los documentos, la construcción del verosímil histórico y el significado tanto estético como político de seguir, con todo, produciendo imágenes.

\section{Notas}

1. En este trabajo se asume la complejidad de las disparidades entre historia y memoria, aunque no se trate de diferencias irreconciliables. Se sigue a Benedict Anderson, quien sostiene que la historia emerge cuando la memoria dejó de existir y se sitúa por fuera 
de grupos específicos aunque ella misma se vuelva creadora de memorias, hecho que resulta patente en la creación de estados nacionales que han recurrido a ella el como una herramienta central para la construcción de identidades colectivas. Véase: Anderson, B. Anderson, B. (1993). Comunidades imaginadas. Reflexiones sobre el origen y la difusión del nacionalismo. México: Fondo de Cultura Económica.

2. En este apartado amplío algunas lecturas sobre la obra de res que fueron presentadas en mi artículo (2017). "La articulación de lo memorable: historia e inscripción en dos series fotográficas de res”. En Meridional. Revista Chilena de Estudios Latinoamericanos. nro.9. pp. 211-234.

3. Me refiero, por ejemplo, a: ¿Dónde están? (1984-1989), una serie que representa imágenes fantasmales con fragmentos del cuerpo humano y un tapir nonato encerrados en frascos de vidrio que flotan sobre un tramo de la autopista donde había funcionado el centro clandestino de detención El Atlético (aunque la elección del espacio fue intuitiva ya que este dato res no lo conocía al momento de elaborar la obra); La ruta de Cortés (19992000), donde el artista recorre el mismo trayecto seguido por el conquistador español en 1519 desde la isla de Cozumel hasta la que fuera la ciudad de Tenochtitlán en México, deteniéndose en imágenes, objetos e íconos que acusan el impacto de la aculturación proveniente de la conquista y del proceso de occidentalización brutal y acelerado de América; o Apoteosis de la libertad (2016), una acción que consistió en invitar a un grupo de personas a "tapiar" la Casa histórica de Tucumán con periódicos publicados a lo largo de doscientos años de historia argentina, produciendo como resultado una imagen alterada del icónico edificio. Véase el número 3 de la revista Ojozurdo: fotografía y política, julio de 2018.

4. También se documentó y nutrió de diversas lecturas, que problematizan el tiempo en la Historia y en la Filosofía, que acompañaron la elaboración del ensayo fotográfico, como Indios, ejército y frontera, de David Viñas (1982) o Calfucurá. La conquista de las pampas, de Álvaro Yunque (1956).

5. Las propiedades técnicas de las fotografías de la serie NECAH 1879 son las siguientes: las de Antonio Pozzo son albúminas de 30 x $40 \mathrm{~cm}$.; las de Res que conforman los dípticos con las primeras, copias tipo C de 80 x $60 \mathrm{~cm}$.; las de No Entregar Carhué Al Huinca, gelatina de plata sobre papel entonada el selenio, $20 \times 25 \mathrm{~cm}$.

6. Esta fotografía figura en el sitio web del artista, en la última edición de la revista Ojozurdo (2018) y fue exhibida, por ejemplo, en la muestra El juicio, lo abyecto y la pata de palo, Centro Cultural Recoleta, 13 de marzo al 14 de abril de 2009.

7. Una mirada crítica que juega con las ambigüedades, ya insinuada en Mi presente perfecto (1999-2000), serie cuyo título contrasta flagrantemente con el conjunto de imágenes que reúne, en una articulación entre la dimensión personal y la social, en el contexto de una de las peores crisis política y social que se vivió en la Argentina a principios del siglo XXI.

8. En una entrevista realizada por Rodrigo Alonso, el crítico señala, a propósito de la construcción de una sexualidad de la mirada, la intertextualidad, guiños o referencias hacia obras tradicionales de la historia de la pintura, como La vuelta del malón (1892), de Angel Della Valle, en Bardo o La ninfa sorprendida (1861), de Édouard Manet, en Retazos del paraíso. Véase: Asseff, A. (2012) "El arte como campo de batalla" (entrevista de Rodrigo Alonso). op. cit., pp. 138 y 139. 
9. En el blog personal del artista se pueden encontrar referencias e información sobre cada una de sus obras y series. En particular sobre La Conquista del Desierto, véase: http:// visitasalpresente.blogspot.com/. Última consulta: 3/10/2018.

10. Véase, en la base de datos autogestiva bola de nieve, una selección de su obra y el pensamiento sobre su propio trabajo o "visión del arte": http://www.boladenieve.org.ar/ artista/697/luna-leonel. Última consulta: 3/10/2018.

11. Este cuadro también es referido como La Conquista del Desierto, Los Conquistadores del Desierto o La revista del Río Negro.

12. Entre las figuras retratadas, se destacan: al centro algunos tenientes coroneles (Levalle, Racedo, Uriburu, Villegas); a la derecha, oficiales y cadetes de marina; a la izquierda, un grupo de indios, un capellán y una cautiva con un niño en brazos; detrás los científicos que participaron de la expedición y las tropas de caballería, artillería e infantería; y en el ángulo inferior derecho, un perro. En: Amigo Cerisola, R. (1994). "Imágenes para una nación. Juan Manuel Blanes y la pintura de tema histórico en la Argentina”. En Curiel, G., González Mello, R. y Gutiérrez Haces, J. (ed.) XVII Coloquio Internacional de Historia del Arte. Arte, historia e identidad en América: visiones comparativas. Tomo II. México: Universidad Autónoma de México. pp. 326-327.

13. El antropólogo Carlos Masotta recopila, además de las obras de res y Luna, otras intervenciones artísticas y sociales contemporáneas que impugnan, de modos muy diversos, el mito de la Conquista del desierto. En la constelación que arma figuran: el ensayo Indios, ejército y frontera (1982), de David Viñas; un retrato irónico de Hermenegildo Sábat sobre Roca, expuesto en la Biblioteca Nacional en 1992; las manifestaciones que se produjeron en Bariloche en el año 1997 para remover el monumento a Roca; y las acciones públicas organizadas en 2004 en Buenos Aires para la remoción del monumento, acontecimiento que generó un debate en diversos medios de prensa. Véase Masotta, C. (2006). "Imágenes recientes de la 'Conquista del Desierto'. Problemas de la memoria en la impugnación de un mito de origen”. Runa, vol. XXVI. Universidad de Buenos Aires, pp. 225-245.

\section{Referencias bibliográficas:}

Agamben, G. (2011). ¿Qué es lo contemporáneo? Desnudez. Buenos Aires: Adriana Hidalgo.

Amigo Cerisola, R. (1994). "Imágenes para una nación. Juan Manuel Blanes y la pintura de tema histórico en la Argentina”. En Curiel, G., González Mello, R. y Gutiérrez Haces, J. (ed.). XVII Coloquio Internacional de Historia del Arte. Arte, historia e identidad en América: visiones comparativas. Tomo II. México: Universidad Autónoma de México.

Anderson, B. (1993). Comunidades imaginadas. Reflexiones sobre el origen y la difusión del nacionalismo. México: Fondo de Cultura Económica.

Asseff, A. (2011, 12 de noviembre). "Cosecharás tus tempestades” (entrevista de Emanuel Rodríguez). La voz del interior. Disponible en: http://vos.lavoz.com.ar/artes/cosecharastus-tempestades. Última consulta: 2/10/2018.

(2012). Ananké Asseff: obra 1999-2012. Buenos Aires: Ediciones Larivière.

Azoulay, Ariella (2008). The Civil Contract of Photography. New York: Zone Books. 
Benjamin, W. (2008 [1942]). "Sobre el concepto de historia” en Obras 1, 2. Madrid: Abada editores.

Bergson, H. (2006[1896]). Materia y memoria. Ensayo sobre la relación del cuerpo con el espírit. Buenos Aires: Cactus.

Bertúa, P. (2017, mayo-octubre). "La articulación de lo memorable: historia e inscripción en dos series fotográficas de res". En Meridional. Revista Chilena de Estudios Latinoamericanos. nro.9, pp. 211-234.

Collingwood-Selby, E. (2009). El filo fotográfico de la historia: Walter Benjamin y el olvido de lo inolvidable. Santiago: Metales Pesados.

Déotte, J.L. (2013). La época de los aparatos. Buenos Aires: Adriana Hidalgo.

Didi- Huberman, G. (2008). "La emoción no dice 'yo'. Diez fragmentos sobre la libertad estética”. En AA.VV. Alfredo Jaar. La política de las imágenes. Santiago de Chile: ediciones Metales Pesados.

Dubois, Ph. (2008 [1990]). El acto fotográfico. De la representación a la recepción. Barcelona: Paidós.

Fajardo, C. (2012). “Lo sublime en la cultura del mercado”. Sinapsis 4, nro.4, pp. 178-195. González, V. (2006). “La verdad inútil”. En Res. La verdad inútil. Buenos Aires: La marca editora. Halbwachs, M. (2004a [1925]). Los marcos sociales de la memoria. Barcelona: Anthropos. (2004b [1950]). La memoria colectiva. Zaragoza: Prensas Universitarias de Zaragoza.

Koselleck, R. (1993). Futuro pasado. Para una semántica de los tiempos históricos. Barcelona: Paidós.

. (2001). Los estratos del tiempo. Estudios sobre la historia. Barcelona: Paidós.

Kracauer, S. (2008 [1927]). La fotografía y otros ensayos. El ornamento de la masa. Barcelona: Gedisa.

Lissovsky, M. (2003). “A maquina de esperar”. En Gondar, J. y Barrenechea, M. (org.). Memória e Espaço: trilhas do contemporâneo. Rio de Janeiro: 7 Letras.

Malosetti, L. (2006, abril). “Artes de excluir, artes de incluir”. Todavía. nro13. pp. 5-7.

Masotta, C. (2006). "Imágenes recientes de la 'Conquista del Desierto'. Problemas de la memoria en la impugnación de un mito de origen”. Runa. vol. XXVI. Universidad de Buenos Aires,pp. 225-245.

Rancière, J. (1996). El desacuerdo. Política y filosofía. Buenos Aires: Nueva Visión. res (2018, julio). "No parece haber atajos ni caminos fáciles en la relación entre el arte y la política” (entrevista de Ignacio Bisbal). Ojozurdo, fotografía y política. nro 3. s/n.

res (2018,19 de septiembre). "Pasado y presente" (conferencia). Jornadas: 12. Fotografía Latinoamericana. Confluencias y derivaciones: 1978-2018, Sala Azul, Intendencia de Montevideo. Disponible en: https://www.youtube.com/watch?v=4HO1nrNH0Ys. Última consulta: 25/09/2018.

Tatián, Diego (2018, julio). “En busca del tiempo perdido”. Ojozurdo, fotografía y política. nro 3. s/n.

Usubiaga, V. (2012). "Variaciones sobre la pintura en las prácticas artísticas contemporáneas en Argentina”. En Baldasarre María I. y Dolinko S. (ed.). Travesías de la imagen. Historias de las artes visuales en la Argentina. Sáenz Peña: Universidad Nacional de Tres de Febrero. Viñas, D. (1982). Indios, ejército y frontera. Buenos Aires: Siglo XXI. 


\begin{abstract}
The objective of this work is to investigate, in a corpus of contemporary photographs, the relationship between images and historical memory, assuming that it is anachronistic in itself and that it is crossed by the effects of montage, the reconstruction and the concatenation of heterogeneous times. I argue that contemporary photography highlights a conceptual line that explores the anachronism, the confrontation between the past and the present, and that sets tension into the founding narratives and dominant narratives of progress in the Latin American cultural capitals between the end of the 19th century and early twentieth. Starting from the work with photographs that operate as "dialectical images", that is, as fleeting remains or flashes of historical readability, the photographs I analyze condense indications of the present and record remains of the past, in an alternative proposal to the memorial, the archive and the epic, the most transited forms in the politics of memory and reconstruction of memory. They are works that resituate their images in new historical senses, disobeying not only the chronology but the causalities and reconfiguring, in this way, the established historical sense. I will take as an object of analysis the works of: RES, La ruta de Cortés (1999-2000) y NECAH 1879 (1996-2008); Ananké Asseff, "Ananké es necesidad, lo inexorable" (2004-2010); Leonel Luna, Su opulencia es nuestra exclusión, 2001; y Celeste Rojas Mugica, Ejercicios de aridez (work in process).
\end{abstract}

Keywords: Contemporary Latin American photography - Historical memory - Dialectic image - Montage - Discontinuities.

Resumo: O objetivo deste trabalho é indagar, num corpus de fotografias contemporâneas, a relação entre imagens e memória histórica, assumindo que esta é anacrónica em si mesma e que está atravessada pelos efeitos da montagem, a reconstrução e o encadeamento de tempos heterogéneos. Proponho que na fotografia contemporânea se destaca uma linha conceptual que explora o anacronismo, a narrativas de progresso dominantes nas capitais culturais latinoamericanas entre fins de século XIX e princípios do XX. A partir do trabalho com fotografias que operam como "imagens dialécticas", isto é como restos fugaces ou relâmpagos de legibilidad histórica, as fotografias que analiso condensan indícios do presente e registam restos do passado, numa proposta alternativa ao memorial, o arquivo e a épica, as formas mais transitadas em nas políticas da memória e reconstrução da lembrança. Trata-se de obras que resitúan suas imagens em sentidos históricos novos, desobedeciendo não só a cronología sina as causalidades e reconfigurando, deste modo, o sentido histórico estabelecido. Tomarei como objeto de análise as obras de: RES, La ruta de Cortés (1999-2000) y NECAH 1879 (1996-2008); Ananké Asseff, "Ananké es necesidad, lo inexorable" (2004-2010); Leonel Luna, Su opulencia es nuestra exclusión, 2001; y Celeste Rojas Mugica, Ejercicios de aridez (obra em processo).

Palavras chave: fotografia latinoamericana contemporânea - memória histórica - imagem dialéctica - montagem - descontinuidades.

[Las traducciones de los abstracts fueron supervisadas por el autor de cada artículo] 